\title{
Stability Analysis of Underwater Pipeline Inter Island for Drinking Water
}

\author{
Wati Asriningsih Pranoto \\ Department of Civil Engineering \\ Universitas Tarumanegara \\ Jakarta-Indonesia \\ watip@ft.untar.ac.id
}

\author{
Tri Suyono \\ Department of Mechanical Engineering \\ Universitas Khairun \\ Ternate-Indonesia \\ tri_suyono78@yahoo.com
}

\begin{abstract}
Indonesia is an archipelago with more than 17 thousand islands, both large and small islands. Some inhabited small islands do not have the potential of fresh water as a source of drinking water, so it needs special treatment in drinking water supply. Provision of drinking water with high technology such as reverse osmosis (RO) is often an obstacle both in terms of investment and operations and maintenance. One technique that is effective in providing drinking water for uninhabited island is the installation of inter-island underwater drinking water pipes. Sub sea pipeline installation is one of the jobs that require careful calculation and method, considering this work is a complex job and has a high risk, both during the installation process and after installation. At the time of installation must use a safe method for workers and the pipe to be installed, while after installation is necessary the stability of the pipe so that the pipe is safe on the seabed, can withstand the strong currents of the sea and the wave effect for the pipe in the shallow area. In the installation of subsea pipelines, it is necessary to take into account some technical aspects that influence the waves, ocean currents, wind speed and depth and structure of the seabed. In the installation of underwater drinking water pipes, it is recommended to use a pipe type of High Density Polyethylene (HDPE) whose specifications are adapted to hydraulic studies taking into account the depth of the sea and water pressure in the pipe, while the weight and distance of the pipe weight concrete are also calculated based on the sea, the speed of the ocean currents, wave height and other technical factors related to pipe stability. The recommended pipe sizes for small islands are $110 \mathrm{~mm}$ in diameter and at least two or three lanes in anticipation of disturbance in one of the pipelines does not interfere with drinking water service on the destination island. The recommended weight of the ballast concrete is between $65 \mathrm{~kg}-80$ $\mathrm{kg}$ with a minimum concrete quality of $\mathrm{K700}$, because this size is still possible to be manually installed with human power, so the distance between the concrete is arranged to obtain a safe pipe stability. Within a period of three months the concrete will be stable and safe from ocean currents because concrete has been bound to the ocean floor by marine biota, especially oyster shells.
\end{abstract}

Keywords-Drinking Water; Underwater Pipes; Sinking

\section{INTRODUCTION}

Drinking water is a basic human need, whose availability becomes mandatory. In Indonesia drinking water supply is the responsibility of the government (central and regional government), so the government is required to provide drinking water that meets $4 \mathrm{~K}$ (quantity, continuity, quality and afford ability). So, in addition for drinking water must meet the quality standard requirements, it must also be affordable by the public. So that the application of high technology with high production costs so that the selling price of water becomes high in some areas will be contrary to the aspects of afford ability.

The construction of drinking water facilities and infrastructure must be carried out in accordance with community needs and geographical conditions and their potential. Many uninhabited islands in Indonesia do not have enough fresh water potential, both surface and ground water, so that some islands need to apply special technology whose operational and maintenance costs are not large, so as not to burden the community with high water prices. One way to meet the drinking water needs of small islands in Indonesia is by constructing inter-island drinking water pipelines with subsea pipelines [3].

As an effort to meet the drinking water needs of small islands that do not have the potential of drinking water, the low operating costs are by constructing sub sea pipelines with cheaper methods and costs than existing methods or technologies. To implement this technology in several regions in Indonesia, one location has been installed between interisland drinking water networks with sufficiently high current and wave waters, with an average depth of 48 meters with a maximum depth of 62 meters, namely the Rum-Maitara subsea pipeline (Tidore Island with Maitara Island) or known as the thousand rupiah island, because these two islands are in the thousand rupiah denomination.

\section{TECHNICAL ASPECTS}

Installation of inter-island underwater drinking water pipelines, one of which is the drinking water pipeline network of Tidore Island to Maitara Island was built by considering several technical aspects namely ocean currents, wave effects and sea floor conditions. The Maitara Strait has a length of about $1,186 \mathrm{~km}$ with a maximum depth of 62 meters and is a narrow, fairly strong strait (ocean currents from the Maluku sea to the waters around Halmahera and vice versa)) where the current in this strait consists of 2 directions one side of the inlet strait and one the outflow side so the installation process is also not easy. This is one of the considerations of pipe construction and also the type of pipe to be used. With various 
considerations and technical studies, the most recommended pipe for this construction is HDPE pipes, and for pipelines from Tidore island to Maitara island with an outer diameter of $3 \times 110 \mathrm{~mm}$. The selection of the three pipelines is taken with consideration if there is damage or interference to one or two pipelines, the system still runs while waiting for repairs to the problematic pipeline network [2].

During the pipe installation process the influence of the wave on the pipe construction will be large when the pipe is on the surface and will gradually shrink with increasing pipe depth. Likewise ocean currents. As for the styles that occur when the pipe in the water gets a force from the ocean currents are as follows:

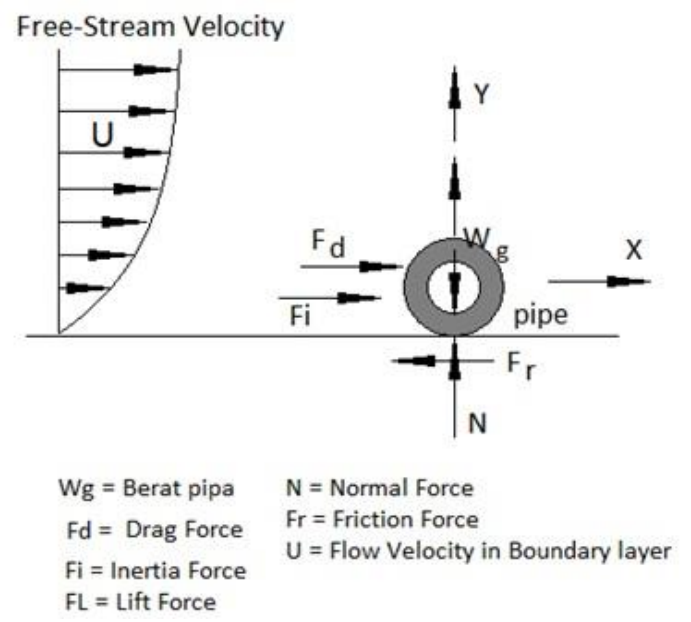

Fig. 1. The forces on the pipe in the water

There are several wave theories. Airy, Stokes, Stream and Current. From surveys conducted in the Hiri Strait, it is assumed that wave conditions follow the Airy wave theory.

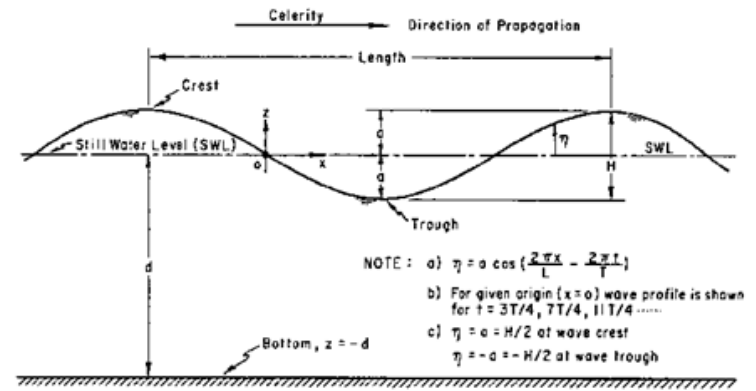

Fig. 2. The movement of the waves

The effect of the wave will be very large if the pipe construction used is near the surface. The more in the position of pipe construction, the smaller the influence of the wave.

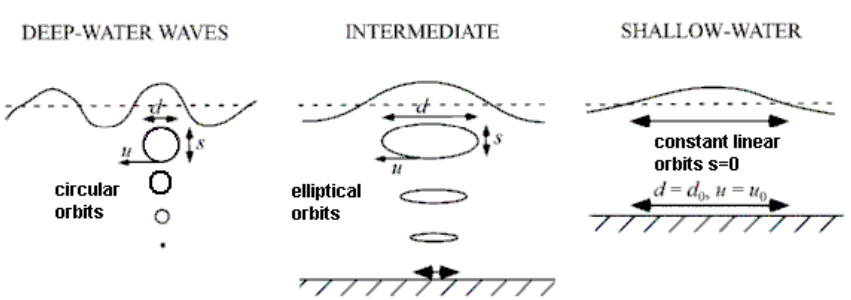

no motion at bed

フフフフフフ

Fig. 3. Effect of waves on depth

Therefore, considering the presence of ocean and wave currents, the installation of drinking water pipes is carried out by sinking on the seabed, so that the effects of waves, currents and deflection due to the weight of the pipe can be minimized [4]. However, it must also be noted that the stability of the pipeline on the seabed (on bottom stability), the influence of pressure and the condition of the seabed will affect the stability of the pipeline [1].

The purpose and purpose of this method is that the installation process of the undersea pipeline runs well and allows it to be carried out by local workforce with a guide of professional and experienced of engineers who also provide technical and economic benefits that can guarantee continuous drinking water service.

\section{Securing The Position Of The PIPE}

Finishing work is done by doing dives to ensure the pipes and ballast are in a safe location, not disturbed by corals or sea troughs which can cause local stresses on the pipes which can cause failure. The things that should be avoided are as follows:

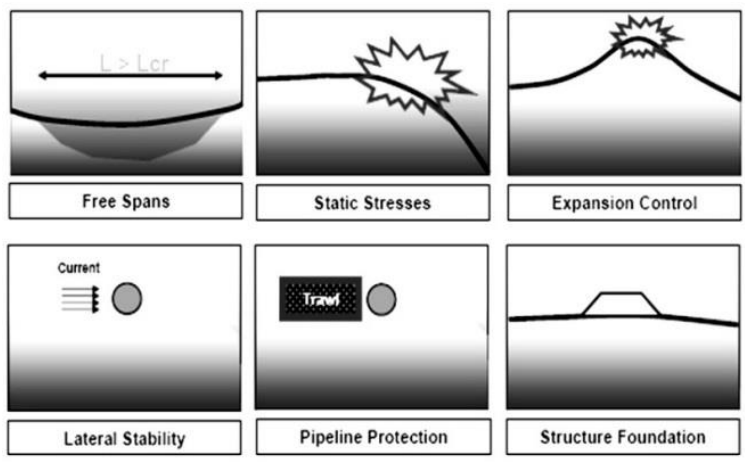

Fig. 4. Things that must be avoided in the installation of subsea pipelines

The trial was carried out by filling the installed pipe with drinking water and flowing continuously for 72 hours so that the resistance and stability of the construction could be known. 


\section{FLOW CHART}

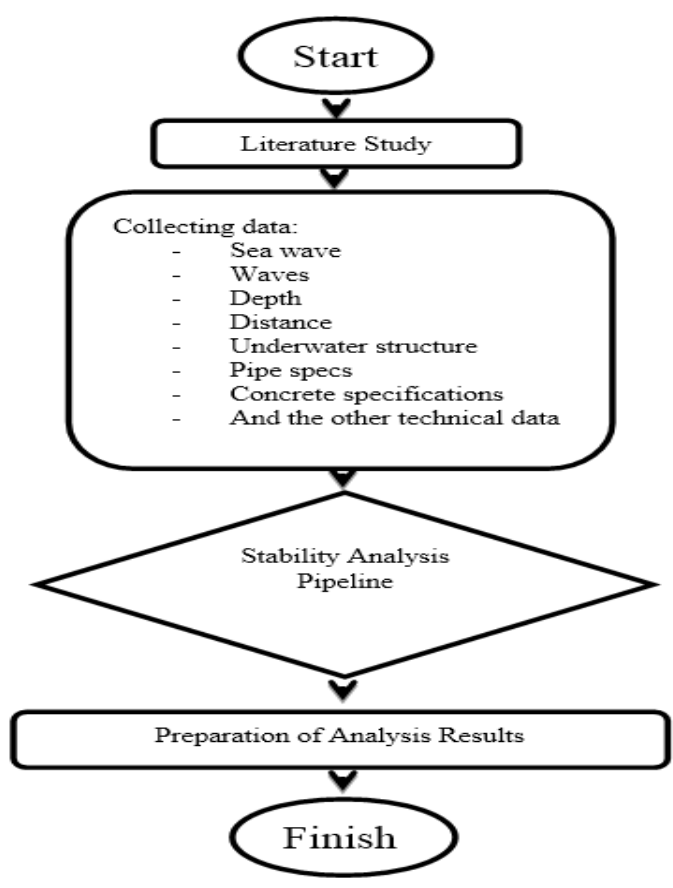

Fig. 5. Flow Chart of The Research

\section{RESULTS AND DISCUSSION}

\section{A. Analysis of pipeline on the seabed}

In general, the installation of subsea pipelines is by placing the pipe on the seabed. In the seabed environment with sufficient depth, the influence of waves and ocean currents is so small that it does not affect the stability of the pipe. However, in-depth knowledge is needed about the underwater conditions themselves [5]. Sufficient studies are needed about the conditions of the underwater, types of seabed, soil, and also the marine environment. Obviously the science of oceanography must be given top priority [6].

Determine minimum concrete load

Analysis of the burden is carried out by giving a load ranging from $5 \mathrm{~kg}$ to $80 \mathrm{~kg}$ weights on the condition of empty or filled pipes will be known the minimum load needed so that the pipe does not float. By looking at the deflection value at the midpoint, the condition of the pipe will be known. For positive results, it means that the deflection is upward or the pipe is floating and if the value of negative deflection means the pipe is sinking as can be seen in table 1.

The ideal weight will make the pipe always sink in empty or filled conditions. But this weight cannot be too large. Giving weight that is too large will cause a very large pipe deflection. From the results of the analysis above, it can be seen that the minimum weight of the concrete ballast installed every $3 \mathrm{~m}$ is $65 \mathrm{~kg}$ per piece. If the weight of the concrete used is less than that then the pipe will float when empty. The condition of this floating pipe will be very dangerous because it will disrupt ship traffic. In addition to the position close to the sea level, the influence of waves and ocean currents will be very large and will cause the pipe to break.

Submarine pipeline installation for $62 \mathrm{~m}$ depth as in the Maitara Strait proved to be quite effective. There are 3 pipelines installed on the Maitara Strait with a length of 1,600 meters. Installation only requires equipment and ships that are not specifically designed for installation of subsea pipelines so that it is more economical.

The weight of the ballast used has a weight of $80 \mathrm{~kg}$ installed every 3 meters so that it will put the pipe in a stable position on the seabed. During the pipe installation process at the seawater side, this is done to ensure the pipeline is in full condition to avoid air being trapped inside the pipe which can result in a decrease in water pressure and thrust, besides that with a full pipe the pipe will be more stable at current conditions and waves and also easy to sink. Below is a picture of the pipe installation documentation that has been carried out.

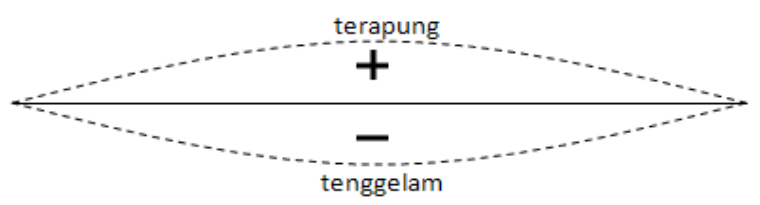

Fig. 6. Direction of deflection

TABLE I. EFFECT OF LOAD ON Pipe Position (FlOATING OR Sinking)

\begin{tabular}{|c|c|c|c|c|c|}
\hline \multirow{3}{*}{ No } & \multirow{3}{*}{$\begin{array}{l}\text { LOAD } \\
(\mathrm{KG})\end{array}$} & \multicolumn{4}{|c|}{ DEFLECTION } \\
\hline & & \multicolumn{2}{|c|}{ EMPTY PIPES } & \multicolumn{2}{|c|}{ PIPE CONTAINED } \\
\hline & & $\begin{array}{c}\text { VALUE } \\
\text { (MM) }\end{array}$ & CONDITION & $\begin{array}{l}\text { VALUE } \\
\text { (MM) }\end{array}$ & CONDITION \\
\hline 1 & $\begin{array}{c}\text { NO } \\
\text { BURDEN }\end{array}$ & 1920570.1 & FLOAT & 116962.9 & FLOAT \\
\hline 2 & 5 & 1800058.1 & FLOAT & -3549.18 & SINK \\
\hline 3 & 10 & 1679546 & FLOAT & -124061 & SINK \\
\hline 4 & 15 & 1559033.9 & FLOAT & -244573 & SINK \\
\hline 5 & 20 & 1438521.9 & FLOAT & -365085 & SINK \\
\hline 6 & 25 & 1318009.8 & FLOAT & -485598 & SINK \\
\hline 7 & 30 & 1197497.8 & FLOAT & -606110 & SINK \\
\hline 8 & 35 & 1076985.6 & FLOAT & -726622 & SINK \\
\hline 9 & 40 & 656473.63 & FLOAT & -847134 & SINK \\
\hline 10 & 45 & 835961.63 & FLOAT & -967646 & SINK \\
\hline 11 & 50 & 715449.44 & FLOAT & -1088158 & SINK \\
\hline 12 & 55 & 594937.44 & FLOAT & -1208670 & SINK \\
\hline 13 & 60 & 474425.38 & FLOAT & -1329182 & SINK \\
\hline 14 & 65 & -971719.44 & SINK & -2775327 & SINK \\
\hline 15 & 70 & -1212743.6 & SINK & -3016351 & SINK \\
\hline 16 & 75 & -1453767.8 & SINK & -3257375 & SINK \\
\hline 17 & 80 & -1694792 & SINK & -3498399 & SINK \\
\hline
\end{tabular}

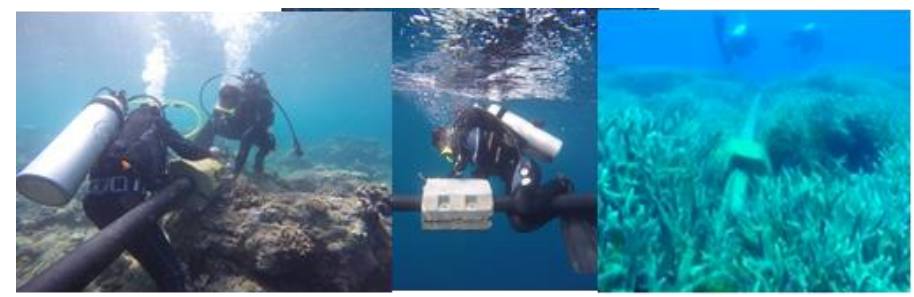

Fig. 7. Underwater Pipe Installation Process 


\section{CONCLUSION AND RECOMMENDATION}

\section{A. Conclusion}

Underwater Pipe Stability can be achieved by taking into account the size of the pipe Recommended for small islands is $110 \mathrm{~mm}$ in diameter and a minimum of two or three lanes in anticipation of disturbance in one of the pipelines does not interfere with drinking water service on the destination island. The recommended weight of the ballast concrete is between $65 \mathrm{~kg}-80 \mathrm{~kg}$ with a minimum concrete quality of K700, because this size is still possible to be manually installed with human power, so that the distance between the concrete is arranged to obtain a safe pipe stability. Within a period of three months the concrete will be stable and safe from ocean currents because concrete has been bound to the ocean floor by marine biota, especially oyster shells. The selection of pipes should minimize the number of connections, for pipes with diameters of $63 \mathrm{~mm}, 90 \mathrm{~mm}$ and $110 \mathrm{~mm}$ should choose a roll pipe with a length of 100 or 200 meters / roll, while for pipe diameters of $160 \mathrm{~mm}$ in diameter should choose a minimum length of 12 meters / rod. In the pipe connection should be given a safety connection so that the connection is not separated and can survive in accordance with the life of the pipe in the water.

\section{B. Recommendation}

In the installation of sub-sea pipelines, it is necessary to pay attention to the problem of strengthening the concrete binder with a pipe, so that the concrete is actually attached to the specified installation point, because otherwise the concrete will shift due to ocean currents before fusing with coral reefs on the seabed.

\section{REFERENCES}

[1] Z. Abidin. Analisis On-Bottom Stability dan Instalasi Pipa Bawah Laut di Daerah Shore Approach, Bandung: Institut Teknologi Bandung, 2008.

[2] W.S. Hardi, "Teknik Pemasangan Pipa Air Minum Bawah Laut dengan Metode TT dari Pulau Tidore ke Pulau Maitara," [Sem. Marit. Sains Tek. Terap., vol. 1., 2016].

[3] H. Liu, Pipeline Engineering, Florida: Lewis Publishers, 2003.

[4] M.A.A. Masrukhin, D.N. Sugianto, and A. Satriadi, "Studi Batimetri dan Morfologi Dasar Laut (Perairan Larangan-Maribaya, Kabupaten Tegal),"J. Oseanografi, vol. 3, 2014.

[5] C. Sibuea, Y. Mulyadi, and I. Rochani, "Analisis On-Bottom Stability dan Local Buckling: Studi Kasus Pipa Bawah Laut dari Platform ULA menuju Platform UW," J. Tek.. ITS, vol. 5, 2016.

[6] Suyadi. "Pengaruh Cacat Las pada Sambungan Pipa Bawah Laut (Girth Weld) dengan Mengaplikasikan Failure Analysis Diagram (FAD)," Gema Tek., vol. 16, pp. 57-62, 2010. 